\title{
Risks of a town-forming enterprise in the risk system of a company town
}

\author{
V.S. Antonyuk ${ }^{1, *}$, I.V. Danilova ${ }^{1}$, and G.V. Erlikh $^{1}$ \\ ${ }^{1}$ South Ural State University, Chelyabinsk, Russia
}

\begin{abstract}
The article is devoted to review of risks of a town-forming enterprise in the risk system of the company town counterparties (infrastructure, population, small and medium business, local self-government authorities). It contains an algorithm of stepwise study of risks of a town-forming enterprise from the perspective of their interconnection with the risk system of the company town counterparties. Approbation of theoretical and methodical provisions by the example of town-forming enterprise Asha Metallurgical Plant OJSC, Asha, Chelyabinsk region, with the help of the graph theory allowed to analyze interconnections and dependence of risks of the town-forming enterprise and to make a conclusion on its negative role in creation of a crisis situation in the economy of the company town. The article is completed with a complex of lines for neutralization of risks of AMP OJSC: TFE's infrastructural and technological risk management; personnel risk management policy; mitigation of consumer, product and supply risks; competitive struggle risk management and advertising risk management.
\end{abstract}

\section{Introduction}

A special form of the settlement and production system is company towns, which town-forming basis is laid by one or few industrial enterprises.

Town-forming enterprises (TFE) are legal entities, in which the number of employees comprises no less than 25 $\%$ of the economically active population of a revenant settlement [1].

Currently there are about 319 Russian towns with single-industry production [2], their territory is occupied by $25 \%$ of the urban population, and the aggregate gross regional product comprises $40 \%$ of the GRP of the RF regions [3, p. 141].

Vitality of the research is connected with the fact that a town-forming enterprise by virtue of its monopoly position has a considerable influence on all the counterparties of the monotown: it determines the level of household income and well-being of the population, influences social and technical infrastructure, limits the value of the demand for products of small business and local industry, influences the income basis of the local budget. Besides, domination of one focused enterprise considerably strengthens vulnerability of the monotown and makes it a "hostage" of the global market situation.

\section{Overview of economic references}

Problems of the general theory of risks (scientific works of Vishnyakov Ya. D, Radaev N.N. [4]), as well the theory of uncertainty and risks of industrial enterprises (works of McCarthy M.P., Flynn T.P [5], Burkov V.N., Kireeva E.A.
[6], Kleiner G.B., Tambovtsev V.L., Kachalov R.M. [7]) have been rather widely studied in the economic literature.

Problems on functioning of TFEs of company towns in the part of studying development trends in the crisis conditions, as well as their recovery ability have been studied in the works of such economists as: Trifonov V.A., Lobanov M.M. [8], Kleiner G.B. [9], Ryakhovskaya A.N., Kovan S.E., Kryukova O.G. [10], Turgel I.D. [11], Kokh I.A. [12], Lyubovny V.Ya. [13].

It is also worth noticing methodical approaches to study of TFEs and monotowns, among which most interesting are guidelines on preparation and implementation of complex investment plans of company town development [14].

\section{Theory and methodology of analysis of risk dependence of a town-forming enterprise}

The task of the article is studying of risks of a town-forming enterprise in the part of their interconnection and dependence on the system of internal and external risks of a company town for development of proposals on their neutralization.

Risk (risqué (French)) is literally defined as a cliff, a rock $[15$, p. 616]. In the economical literature risk is defined as potential occurrence of events with negative consequences as a result of certain decisions or actions [16, p. 898]. In the theory of risks the notions of factor (cause), type of risks and type of losses (damage) are differentiated $[17, \mathrm{p} .12]$.

The algorithm of solving of the set task consists of the following stages:

Corresponding author: antvs@list.ru

C) The Authors, published by EDP Sciences. This is an open access article distributed under the terms of the Creative Commons Attribution License 4.0 (http://creativecommons.org/licenses/by/4.0/). 
- analysis of risks of individual monotown counterparties (TFE, population, infrastructure, small and medium business, local self-government authorities) with identification of risk factors, probability of occurrence and damage;

- ranging of risks by the monotown components;

- analysis of interdependence of TFE's risks on the risk system of the town counterparties and building of causeand-effect links with the help of the graph theory;

- development of a complex of measures aimed at neutralization of risks of a town-forming enterprise.

\section{Risks of monotown counterparties}

This procedure has been approved by the example of analysis of the situation in monotown Asha of Chelyabinsk region in 2010, which forming enterprise is Asha Metallurgical Plant OJSC (AMP OJSC). Initially we conducted expert analysis, which allowed to identify most typical risks of the monotown counterparties:

- risks of AMP OJSC (infrastructural; technological; personnel; consumer; product risks; as well as risks connected with owners);

- risks of population (risks of labor power migration; risks of population's paying capacity; risks of reduction of living standards and human capital assets);

- risks of infrastructure (depreciation; expiration of the life cycle of infrastructural elements; lack of capacity / availability of infrastructure; influence of external natural

and man-made factors; lack of financing; title to infrastructure);

- risks of local industry and small business (infrastructural; social and consumer);

- risks of local self-government authorities (political and credit risks; risks of volatility of outgoing payments and volatility of collected taxes; risks of undistributed liabilities).

Then, we ranged the risks by the monotown components, when the range of each of them is determined as a product of the average weighted (by the degree of influence) probability of activation of each factor by the average weighted damage assessment, as a result of which we obtained "the rose of risks" by the monotown components (fig. 1).

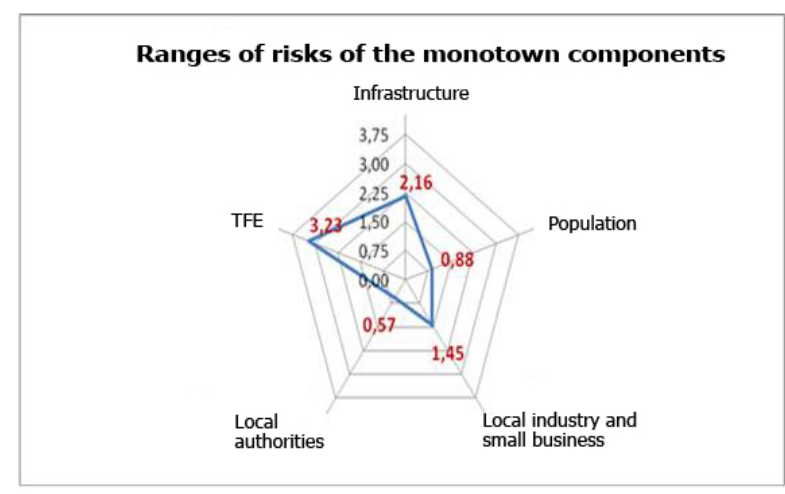

Fig. 1. "Rose of risks" by the monotown components.

Table 1. Risks of AMP OJSC in the risk system of Asha, Chelyabinsk region.

\begin{tabular}{|c|c|c|}
\hline \# & Risk & Dependent risks \\
\hline 1 & TFE's supply risks & TFE's product risk \\
\hline 2 & TFE's competitive struggle risk & TFE's consumer risks, TFE's personnel risks \\
\hline 3 & TFE's advertising risk & TFE's competitive struggle risk, TFE's consumer risks \\
\hline 4 & $\begin{array}{l}\text { Risk connected with the TFE's distribution } \\
\text { system }\end{array}$ & TFE's supply risks, TFE's consumer risks \\
\hline 5 & TFE's consumer risks & TFE's personnel risks; risk connected with infrastructural financing \\
\hline 6 & TFE's product risks & TFE's consumer risks \\
\hline 7 & TFE's personnel risks & $\begin{array}{l}\text { TFE's supply risks; TFE's advertising risk; risk connected with the TFE's } \\
\text { distribution system; TFE's product risks; risk of the population's paying capacity; } \\
\text { risk of reduction of the population's living standards }\end{array}$ \\
\hline 8 & TFE's infrastructural risks & TFE's supply risks; Risk connected with the TFE's distribution system \\
\hline 9 & Risks of tax collection volatility & $\begin{array}{c}\text { Risk of reduction of the population's living standards; risk connected with } \\
\text { infrastructural financing }\end{array}$ \\
\hline 10 & Risk of the population's paying capacity & $\begin{array}{l}\text { Risks of tax collection volatility; consumer risks of local industry and small } \\
\text { business; risk connected with infrastructural financing }\end{array}$ \\
\hline 11 & $\begin{array}{c}\text { Risk of reduction of the population's living } \\
\text { standards }\end{array}$ & Social risks of local industry and small business \\
\hline 12 & $\begin{array}{l}\text { Infrastructural risks of local industry and } \\
\text { small business }\end{array}$ & Risks of tax collection volatility \\
\hline 13 & $\begin{array}{c}\text { Consumer risks of local industry and small } \\
\text { business }\end{array}$ & Risks of tax collection volatility; риск, risk connected with infrastructural financing \\
\hline 14 & $\begin{array}{c}\text { Depreciation / wear of infrastructural } \\
\text { elements }\end{array}$ & $\begin{array}{l}\text { Expiration of the life cycle of infrastructural elements; lack of capacity / availability } \\
\text { of infrastructure }\end{array}$ \\
\hline 15 & Risk connected with infrastructural financing & $\begin{array}{l}\text { Depreciation / wear of infrastructural elements; expiration of the life cycle of } \\
\text { infrastructural elements; lack of capacity / availability of infrastructure }\end{array}$ \\
\hline 16 & $\begin{array}{c}\text { Expiration of the life cycle of infra-structural } \\
\text { elements }\end{array}$ & $\begin{array}{l}\text { TFE's infrastructural risks; risk of reduction of the population's living standards; } \\
\text { infrastructural risks of local industry and small business; lack of capacity / } \\
\text { availability of infrastructure }\end{array}$ \\
\hline 17 & $\begin{array}{l}\text { Lack of capacity / availability of } \\
\text { infrastructure }\end{array}$ & $\begin{array}{c}\text { TFE's infrastructural risks; risk of reduction of the population's living standards; } \\
\text { Infrastructural risks of local industry and small business }\end{array}$ \\
\hline
\end{tabular}

As it is clear from the ranging, risks connected with the activity of the town-forming enterprise (range 3,23) and infrastructural risks (range 2,16) have the maximum negative influence on the activity of Asha. 


\section{Dependence of risks of a town- forming enterprise}

At the next stage we studied interconnections and dependence of TFE's risks on risks on other town counterparties with the help of the graph theory $[18,19$, 20]. Table 1 contains a system of risks of AMP OJSC in the monotown risk system and their interconnections.

In figure 2 external, internal and external-internal risks are shown as points, and the system of interconnection and interdependence of risks - as arcs, wherein a high degree of interconnection is marked with a thick line.

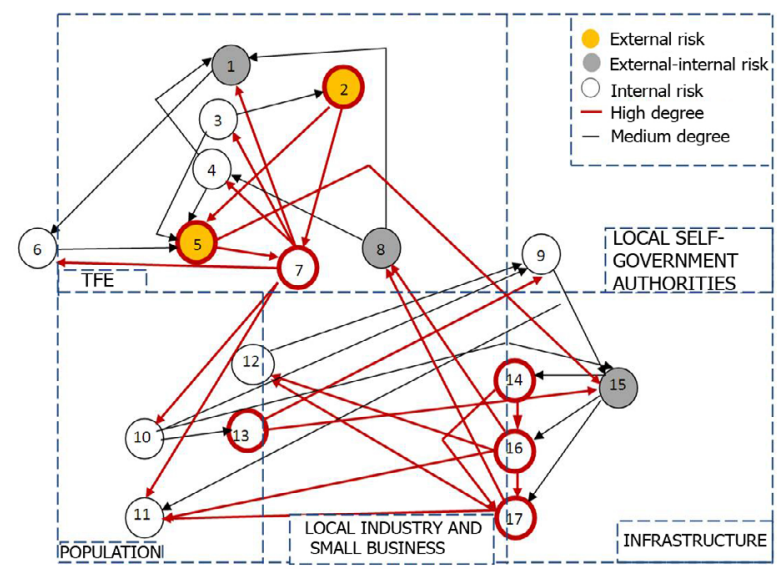

Fig. 2. Dependence of risks of AMP OJSC in the risk system of Asha, Chelyabinsk region.

We can make the following conclusions of the conducted analysis of risk dependence.

Firstly, risks of the town-forming enterprise and infrastructure are most vulnerable for a company town. Thus, out of 17 types of risks 8 are inherent of AMP OJSC and 4 - of the technical infrastructure.

Secondly, the main types of risks for the townforming enterprise are: competitive struggle risk, consumer risks, personnel risks, and for infrastructure - depreciation, expiration of the life cycle of infrastructural elements, lack of capacity / availability of infrastructure.

Thirdly, AMP OJSC is characterized both by internal (advertising risk; risk connected with the distribution system; product risk; personnel risks) and external-internal and external risks (supply risks; competitive struggle risk; consumer risks and infrastructural risks). Technical infrastructure is basically characterized by risks internal in relation to the town, which is quite explainable, whereas infrastructure is a tertiary sector for the town counterparties.

Fourthly, town-forming enterprises are a rather unstable form of enterprises, whereas they are characterized by a high degree of field specialization and a low level of field diversification, which makes them rather dependable on the global economic situation. In modern conditions this situation is aggravated by the global crisis and metal price collapse tendencies.

\section{Conclusion}

Thus, practical value of the research is that it allows to identify most typical risks characteristic of Asha Metallurgical Plant OJSC and to develop lines for their neutralization. The most important lines include: 1) TFE's infrastructural risk management by means of:

- elimination of failures in operation of the logistical infrastructure (failures in transport operation, problems with availability of storage areas, etc.);

- search of new partners or specialists able to ensure support service;

2) Technological (production) risk management on account of:

- motivation of operational personnel;

- increase of the product quality control level;

- upgrade of the production management quality;

3) Personnel risk management aimed at nonadmission of dismissal of qualified personnel;

4) Consumer risk management, for which purpose we need:

- availability of information on the market condition;

- marketing analysis of the market and stimulation of product demand;

- increase of marketing allocations;

5) Product risk management on account of:

- improvement of consumer and functional product properties, increase of awareness;

- improvement of pricing;

6) Supply risk management aimed at increase of the materials quality control level and improvement of acquisition planning;

7) Competitive struggle risk management by increase of awareness on the market condition, its competitors and new players;

8) Management of risks connected with the distribution system and availability of sales partners;

9) Advertising risk management on account of:

- bringing of the product information to the knowledge of potential buyers and improvement of advertising financing.

Thus, system risk management of a town-forming enterprise built on a periodic basis and in the mode of continuous monitoring of external and internal risks will allow to ensure compensation of its risks, balanced state of the company town and improvement of the population's well-being in conditions of an extremely unstable global market situation.

The authors make conclusions on the research work and give recommendations on application of the obtained results.

The work was supported by Act 211 Government of the Russian Federation, contract № 02.A03.21.0011

\section{References}

1. Federal law no. 127-FZ dated 2002, On insolvency (bankruptcy) (2002)

2. Resolution of the RF Government no. 1398-r (2014) 
3. O. Roy, Basics of State and Municipal Administration: Manual (Piter, St. Petersburg, 2013)

4. Ya.D. Vishnyakov, N.N. Radaev, General Theory of Risks (Akademia Publishing center, Moscow, 2007)

5. M.P. McCarthy, T.P. Flynn, Risk: Risk Management at the Level of Top Management and Board of Directors (Alpina Business Books, Moscow, 2005)

6. E.A. Kireeva, V.N. Burkov, Proc. XII All-Russian Conference on Management Problems (ARCPM)2014, 5309-5319 (2014)

7. G.B. Kleiner, V.L. Tambovtsev, R.M. Kachalov, Enterprise in an Unstable Economic Environment: Risks, Strategy, Security (Economics, Moscow, 1997)

8. V.A. Trifonov, M.M. Lobanov, News of Tomsk Polytechnic University, 309, 3, 198-201

9. G.B. Kleiner, ECO, 6, 187-192 (2007)

10. A.N. Ryakhovskaya, S.E. Kovan, O.G. Kryukova, Prevention of Bankruptcy of Town-Forming Organizations of Company Towns: monograph (Magistr: Infra-M Scientific and Publishing Center, Moscow, 2012)

11. I.D. Turgel, Russian Company Towns: from Survival to Stable Development (Publishing house of the Ural State University of Economics, Yekaterinburg, 2010)

12. I.A. Kokh, Issues of Management, 9, 75-84 (2009)

13. I.A. Lyubovny, Company Towns in Crisis Conditions: Condition, Problems, Recovery
Opportunities (Dortranspechat CJSC, Moscow, 2009)

14. Guidelines on Preparation and Implementation of Complex Investment Plans of Company Town Development. gov.cap.ru/HOME/24/oip/17.doc.

15. L.P. Krysin, Illustrated definition dictionary of foreign words (Eskimo, Moscow, 2011)

16. A.N. Azrilian, Great Dictionary of Economics (Institute for New Economic Thinking, Moscow, 2002)

17. I.N. Kalashnikova, Economic Analysis: Theory and Practice, 13(220), 10-18 (2011)

18. K. Berzh, Graph Theory and its Applications (Foreign Literature, Moscow, 1962)

19. T.A. Khudyakova, A.V. Shmidt, Proc. of The 26th International Business Information Management Association Conference, 1612-1616 (2015)

20. T.A. Khudyakova, A.V. Shmidt, Proc. of The 26th International Business Information Management Association Conference, 1617-1625 (2015)

21. V.N. Burkov, A.Yu. Zalozhnev, D.A. Novikov, Graph Theory in Organizational System Management (Sinteg. Organizational System Management, Moscow, 2001)

22. V.N. Burkov, V.N. Zinchenko, S.V. Sochnev, G.S. Khulap, Exchange Mechanisms in the Economy of the Transition Period (Institute of Control Sciences of the Russian Academy of Sciences, Moscow, 1999) 